\title{
Nanoparticle number from biodiesel blends combustion in a common rail fuel injection system diesel engine equipped with exhaust gas recirculation
}

\begin{abstract}
The paper presents characterisations of nanoparticle number in exhaust gases from biodiesel blends (B30, 30\% of RME by volume with ultra low sulphur diesel fuel, ULSD) combustion in a V6 diesel engine equipped with a common rail fuel injection system. The engine was operated on three steady-state test points extracted from the New European Driving Cycle without engine hardware or the engine management system (EMS) modification. A fast differential mobility spectrometer was used to determine particle number size distribution based on electrical mobility equivalent diameter. The distribution was dependent on the engine operating condition and the rate of exhaust gas recirculation (EGR). The particle size in the nucleation mode from B30 combustion with and without EGR is smaller than that of ULSD while giving higher number concentration for all engine operating conditions tested. However, in the accumulation mode with and without EGR, the smaller sizes and the lower total numbers from B30 combustion were observed. For both fuels, EGR shows insignificant changes to the primary particle size but noticeable increase in particle size and number in the accumulation mode. In overall, compared to the ULSD case, the B30 combustion reduced particle size and lowered total particle number in exhaust gas emitted from the engine with EGR.
\end{abstract}

Key words: nanoparticle, biodiesel, diesel, particulate matter, particle number, size distribution, common rail, exhaust gas recirculation, nucleation, accumulation

\section{Liczba nanocząstek ze spalania mieszanek z biodieslem w silniku ZS z ukladem wtryskowym z ciśnieniowym kolektorem paliwa common rail wyposażonym w układ recyrkulacji spalin}

\begin{abstract}
$W$ artykule przedstawiono charakterystykę ilościowa nanoczastek $w$ gazach spalinowych ze spalania mieszanek z biodieslem (B30, mieszanka 30\% obj. estru metylowego oleju rzepakowego RME z ultraniskosiarkowym olejem napędowym ULSD) w silniku z zapłonem samoczynnym V6 wyposażonym w układ wtryskowy z ciśnieniowym kolektorem paliwa common rail. Badania przeprowadzono $w$ trzech ustalonych stanach obciażenia, wyjętych z Nowego Cyklu Europejskiego, bez modyfikacji systemu silnika oraz układu sterowania silnikiem EMS. Szybki różnicowy spektrometr mobilności DMS zastosowano do określenia rozkładu ilościowego czasteczek, opartego na równoważnej średnicy mobilności elektrycznej. Rozkład okazat się zależny od stanu operacyjnego silnika i stopnia recyrkulacji spalin EGR. Wymiary czastek w zakresie nukleacyjnym przy spalaniu paliwa B30 z udziatem i bez udzialu EGR sq mniejsze niż przy spalaniu ULSD, natomiast ich koncentracja ilościowa jest większa we wszystkich badanych stanach operacyjnych silnika. Natomiast w zakresie akumulacyjnym zaobserwowano mniejsze wymiary i mniejsza catkowita liczbe czastek przy spalaniu B30, zarówno z udziałem, jak i bez udziału recyrkulacji spalin EGR. Dla obydwu paliw zastosowanie EGR powoduje nieznaczne zmiany w wymiarach cząstek pierwotnych, lecz znaczacy wzrost wymiarów $i$ liczby cząstek $w$ zakresie akumulacyjnym. Ogólnie biorac, $w$ porównaniu ze spalaniem ULSD spalanie mieszanki B30 spowodowato zmniejszenie wymiarów czastek i obniżenie całkowitej ich ilości $w$ gazach spalinowych z silnika pracujacego z udziatem recyrkulacji spalin EGR.
\end{abstract}

Słowa kluczowe: nanocząstki, biodiesel, diesel - olej napędowy, czastki stałe, liczba cząstek, rozkład wielkości, kolektor paliwa, recyrkulacja gazów spalinowych, nukleacja, akumulacja

\section{Introduction}

Biodiesel fuels in the form of methyl or ethyl esters are oxygenated derivative from a wide variety of renewable sources such as vegetable oil, waste cooking oil, and animal fat [1]. They are being gained more attention as an alternative fuel for compression ignition (diesel) engines. Some of their key properties are comparable to those of diesel fuel. Near-zero sulphur and aromatic contents in biodiesel are considered to be advantageous over fossil fuels. In addition, promotions to use other renewable bio-fuels in transporta-

\section{Wstęp}

Paliwa biodieslowskie (biodiesle) w postaci estrów metylowych lub etylowych są utlenionymi produktami pochodnymi z szerokiej gamy źródeł odnawialnych, takich jak oleje roślinne, zużyte oleje ze smażenia czy tłuszcze zwierzęce [1]. Jest nimi coraz większe zainteresowanie jako alternatywnymi paliwami dla silników z zapłonem samoczynnym (ZS). Niektóre z ich kluczowych właściwości są porównywalne $\mathrm{z}$ właściwościami oleju napędowego. Bliska zeru zawartość siarki i związków aromatycznych 
tion [2] and environmental concerns on carbon dioxide $\left(\mathrm{CO}_{2}\right)$ emissions are probably the main reasons for instigating the use of biodiesel as a part-substitute for diesel fuel.

Generally biodiesel and its blends reduce carbon monoxide, total unburned hydrocarbon, soot (solid carbon fraction of PM) and PM mass emissions compared to standard diesel, while increasing nitrogen oxides when combusted in stock engines without timing changes or exhaust gas after treatments [3]. For some other unregulated emissions, polycyclic aromatic hydrocarbon (PAH) and nitro PAH compounds are considerably reduced by the use of biodiesel, as well as the lower levels of some toxic and reactive hydrocarbon species determined by chemical characterisation [4].

Kittelson [5] described a typical particulate size characterisation of diesel aerosols in form of tri-modal and log-normal distribution. The so-called nuclei mode comprises spherical primary particles ranging from 5 to $50 \mathrm{~nm}$ diameter with a tiny amount of mass. Primary particles are agglomerated into aggregates, fairly similar to fractal-like shape [6]; the size is therefore determined by equivalent diameter of fractal-like particles. Accumulation mode is the subsequence range containing particle size from 50 to $1,000 \mathrm{~nm}$ diameters with a lower number of particles but higher total particulate mass compared to the nuclei mode. The coarse mode contains particles larger than 1,000 nm in diameter; it is not presented here due to the limitation of the spectrometer used in this work.

Research work concerning diesel particulate matter has been previously conducted at the authors' laboratory in Birmingham. Tsolakis et al. [7] investigated the particulates in the exhaust gases from a dual fuel (hydrogen-diesel) engine. Tsolakis [8] examined the exhaust PM from a single cylinder diesel engine equipped with pump-line-injector fuel injection system and fuelled with neat biodiesel. The particulate size distributions were found to be affected by the use of EGR. The results previously obtained were consistent with those conducted by Chuepeng et al. [9] using a V6 diesel engine equipped with a common rail fuel injection system.

The main aim of this research is to present PM number size distribution and total particle number as a function of their size in nucleation and accumulation modes. An experimental study was conducted using a differential mobility spectrometer (DMS) to examine effects of fuel property on the exhaust gas aerosols from the combustion of diesel-biodiesel blends in a modern multi-cylinder production engine without hardware and EMS modification. This assesses the quantitative impact of high proportion biodiesel blends (B30) on particulate matter as inline with the EU vision for 2030 to promote to use of bio-fuels for road transportation [10].

\section{Experimental apparatus and procedure}

\subsection{Engine and instrumentation}

The experimental work was conducted using a V6 Jaguar diesel engine. The engine conforming to EURO IV emission standard is equipped with twin variable geometry w biodieslach uważane są za zaletę w porównaniu z paliwami kopalnymi. Poza tym zalecenie stosowania biopaliw odnawialnych w transporcie [2] oraz obawy ekologiczne dotyczące emisji dwutlenku węgla $\left(\mathrm{CO}_{2}\right)$ są prawdobodobnie głównymi przyczynami wprowadzania biodiesla jako częściowego substytutu dla oleju napędowego.

Ogólnie biorąc, biodiesel i jego mieszanki spalane w seryjnie produkowanych silnikach bez zmian kąta wtrysku i systemów obróbki spalin dają w porównaniu ze standardowym olejem napędowym zmniejszenie emisji tlenku węgla, niespalonych węglowodorów i sadzy (frakcji stałej fazy węglowej w emisji cząstek) oraz ogólnej emisji cząstek stałych, natomiast zwiększa się emisja tlenków azotu [3]. Spośród innych emisji nieobjętych przepisami, zastosowanie biodiesla znacznie zmniejsza emisje wielopierścieniowych węglowodorów aromatycznych (WWA, PAH) i azotowanych WWA oraz obniża poziom niektórych toksycznych i reaktywnych związków węglowodorowych wyznaczanych metodami chemicznymi [4].

Kittelson [5] opisał typową charakterystykę rozmiarów cząstek w aerozolach z silników ZS w postaci rozkładów trójmodalnych i logarytmiczno-normalnych. Tak zwany zakres zarodkowy obejmuje kuliste cząstki pierwotne o średnicach od 5 do 50 nanometrów, reprezentujące znikomą masę. Cząstki pierwotne łączą się w aglomeraty o kształtach podobnych do fraktalnych [6]; ich rozmiary są w związku z tym określone przez równoważne średnice cząstek typu fraktalnego. Zakres akumulacyjny jest następującym potem zakresem rozmiarów zawierającym cząstki o średnicach od 50 do 1000 nm, o mniejszej liczbie cząstek, lecz większej ich masie w porównaniu z zakresem zarodkowym. Zakres zgrubny zawiera cząstki o średnicach powyżej $1000 \mathrm{~nm}$; nie jest przedstawiany w tym artykule ze względu na ograniczenia spektrometru używanego w tych badaniach.

W laboratorium autorów w Birmingham przeprowadzano już wcześniej badania dotyczące emisji cząstek stałych z silników ZS. Tsolakis i in. [7] badali cząstki stałe w gazie wydechowym z jednocylindrowego dwupaliwowego (wodór - olej napędowy) silnika ZS. Tsolakis [8] badał cząstki stałe w gazie wydechowym jednocylindrowego silnika ZS wyposażonego w system wtryskowy paliwa z pompą liniową i wtryskiwaczem, i zasilanego czystym biodieslem RME. Rozkłady wielkości cząstek stałych okazały się zmienne w efekcie stosowania recyrkulacji gazów spalinowych (EGR). Te uprzednio uzyskane wyniki były też spójne $z$ badaniami przeprowadzonymi przez Chuepenga i in. [9] z użyciem silnika ZS V6 wyposażonego w układ wtryskowy common rail.

Głównym celem przedstawionych tu badań było określenie rozkładu ilościowego cząstek stałych według ich rozmiarów oraz ogólnej liczby cząstek w funkcji ich rozmiarów w zakresach zarodkowych (nukleacyjnych) i akumulacyjnych. Badania eksperymentalne z użyciem różnicującego spektrometru mobilności (differential mobility spectrometer DMS) nakierowane były na określenie wpływu właściwości paliwa na aerozole w gazie wydechowym ze spalania mieszanek oleju napędowego z biodieslem w no- 
turbochargers (VGT) and a Siemens-VDO common rail direct injection system. The engine technologies comprise a cooled exhaust gas recirculation (EGR) system, twin diesel oxidation catalysts (DOCs), and a diesel particulate filter (DPF). Engine specification is given in table 1. An eddy-current type Schenck W230 dynamometer was used to brake the engine on the test rig. Monitoring and recording engine operating parameters (e.g. air and fuel mass flow, start of pre-, main-, and post-injection, intake manifold pressure and temperature etc.) from the engine management system (EMS) were accomplished using INCA software from ETAS.

Table 1. Engine specification

Tabela 1: Dane techniczne silnika

\begin{tabular}{|l|c|}
\hline Bore/średnica cylindra & $81 \mathrm{~mm}$ \\
\hline Stroke/skok ttoka & $88.0 \mathrm{~mm}$ \\
\hline $\begin{array}{l}\text { Displacement volume/objętość } \\
\text { skokowa }\end{array}$ & $2720 \mathrm{~cm}^{3}$ \\
\hline $\begin{array}{l}\text { Maximum torque/max moment } \\
\text { obrotowy }\end{array}$ & $435 \mathrm{~N} \cdot \mathrm{m} @ 1900 \mathrm{rpm}$ \\
\hline Maximum power/max moc & $152 \mathrm{~kW} @ 4000 \mathrm{rpm}$ \\
\hline $\begin{array}{l}\text { Compression ratio/stopień } \\
\text { sprężania }\end{array}$ & $17.3: 1$ \\
\hline
\end{tabular}

\subsection{Particle number and size determination}

The particle sampling shown schematically in Fig. 1 was based on partial flow dilution system. Engine exhaust gases at $20 \mathrm{~cm}$ downstream of turbocharger exit were drawn to a mini diluter with a constant 20 -to- 1 dilution ratio and diluted with zero-grade air from bottle supplied by BOC at controlled

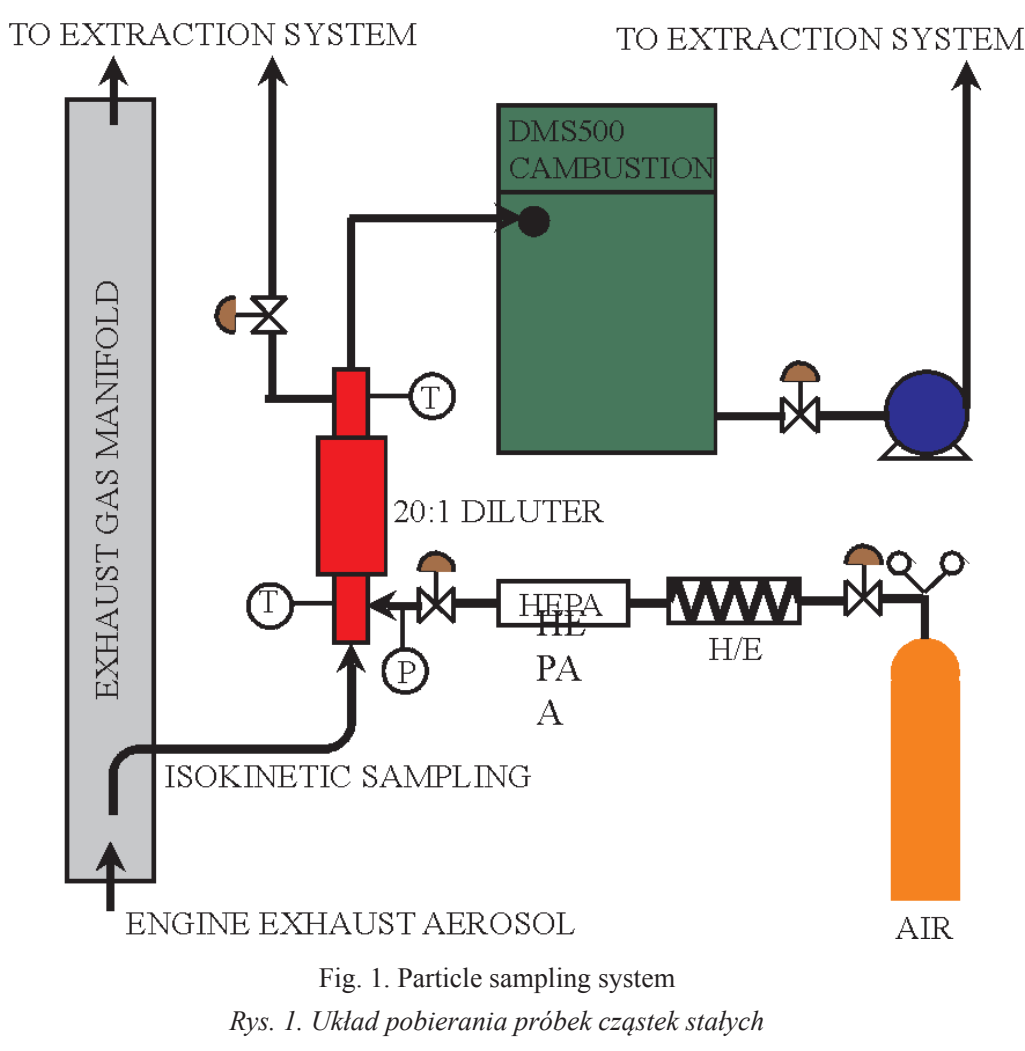

woczesnym wielocylindrowym silniku z produkcji seryjnej, bez modyfikacji zespołów silnika ani też elektronicznych zespołów sterujących. Pozwala to na oszacowanie ilościowego wpływu wysokoprocentowych mieszanek biodiesla (B30) na emisje cząstek stałych zgodnie z wizją Unii Europejskiej na rok 2030, dotyczącą promowania zastosowań biopaliw w transporcie drogowym [10].

\section{Aparatura i procedury badawcze}

\subsection{Silnik i oprzyrządowanie}

Badania eksperymentalne przeprowadzono na silniku o zapłonie samoczynnym V6 Jaguar. Silnik spełniający wymagania normatywne emisji Euro 4 jest wyposażony w bliźniaczy układ turbosprężarek o zmiennej geometrii (VGT) oraz układ bezpośredniego wtrysku paliwa common rail Siemens-VDO . Technologie zastosowane w silniku obejmują chłodzony układ recyrkulacji gazów spalinowych EGR, bliźniacze reaktory utleniające DOC oraz filtr cząstek stałych - DPF. Dane techniczne silnika podano w tabeli 1. Do odbierania mocy silnika na hamowni zastosowano dynamometr prądów wirowych Schenck W230. Monitorowanie i zapis parametrów operacyjnych silnika (np. strumieni masowych przepływów powietrza i paliwa, kątów początku wtrysku wstępnego, głównego i wtórnego, ciśnienia i temperatury $\mathrm{w}$ kolektorze wlotowym itd.) pobieranych z układu sterującego silnika (EMS) dokonywane były przy użyciu oprogramowania INCA firmy ETAS.

\subsection{Określanie liczby i rozmiaru cząstek}

Układ pobierania próbek cząstek, przedstawiony schematycznie na rys. 1, oparty był na systemie częściowego rozrzedzania przepływu. Gazy wydechowe z silnika pobierane były $20 \mathrm{~cm}$ za wylotem z turbospreżarki do minirozrzedzacza (minidiluter) o stałym stosunku rozrzedzania 20:1 i rozrzedzane w kontrolowanych warunkach czystym (jakości zerowej) sprężonym powietrzem z butli dostarczanych przez BOC. Rozrzedzone próbki przepływały strumieniem 8 1/min w warunkach poniżej ciśnienia atmosferycznego do różnicowego spektrometru mobilności - model DMS500 firmy Cambustion Ltd.

Spektrometr mierzy cząstki w zakresie wielkości od 5 do $1000 \mathrm{~nm}$ z opóźnieniem $200 \mathrm{~ms}$ i częstotliwością danych wyjściowych do $10 \mathrm{~Hz}$. Rozkłady ilościowe wielkości cząstek przedstawiane poniżej dla stanów ustalonych każdego z warunków pomiarowych silnika były uśredniane z 30-sekundowego pomiaru. Są one również korygowane na rozrzedzenie i przestawiane jako nierozrzedzone emisje w gazie wydechowym. Całkowita liczba cząstek może być obliczona przez całkowanie powierzchni pod krzywą (dN/dlogDp) w funkcji $\log$ pp w zakresie rozmiarów od 5 do $50 \mathrm{~nm}$ dla cząstek zarodkowych (nukleacyjnych) i 51 do 1000 nm dla zakresu akumulacyjnego.

\subsection{Paliwa badawcze}

W ciągu całego zakresu badań stosowano dwa paliwa podstawowe: olej napędowy 
condition. The diluted samples flowed sub-barometrically at constant rate of $8 \mathrm{l} / \mathrm{min}^{-1}$ into a differential mobility spectrometer model DMS500 from Cambustion Ltd.

The spectrometer measures particles in the size range of 5 to $1,000 \mathrm{~nm}$ at $200 \mathrm{~ms}$ time response with the output data range of up to $10 \mathrm{~Hz}$. The particle number size distributions shown in the following sections representing for each steady-state engine test condition were averaged from 30 seconds. Also, they were corrected for dilution and are shown as engine undiluted exhaust gas emissions. The total particle number can be calculated by integrating the area under the curve $(\mathrm{dN} / \mathrm{d} \log \mathrm{Dp})$ over $\log \mathrm{pp}$ from the size range of 5 to $50 \mathrm{~nm}$ for nucleation mode and 51 to 1,000 $\mathrm{nm}$ for accumulation mode.

\subsection{Test fuels}

Throughout the research work, two base fuels: ultra low sulphur diesel (ULSD) and rapeseed methyl ester (RME) were used. Both were provided by Shell Global Solutions UK and conform to the EN 590 and EN 14214 fuel standards for ULSD and RME, respectively. Some of their key properties are shown in table 2. For all engine conditions, the test was performed using two different fuel contents: ULSD and volumetric blend of 30\% RME with 70\% ULSD (namely B30 hereafter).

Table 2. Fuel properties

Tabela 2. Właściwości paliw

\begin{tabular}{|l|c|c|}
\hline & ULSD & RME \\
\hline Cetane number/liczba cetanowa & 53.9 & 54.7 \\
\hline $\begin{array}{l}\text { Density at } 15^{\circ} \mathrm{C}\left(\mathrm{kg} \cdot \mathrm{m}^{-3}\right) / \text { gęstość } \\
\text { przy } 15^{\circ} \mathrm{C}\end{array}$ & 827.1 & 883.7 \\
\hline Viscosity at $40^{\circ} \mathrm{C}(\mathrm{cSt}) /$ lepkość & 2.467 & 4.478 \\
\hline $\begin{array}{l}\text { LHV }\left(\mathrm{MJ} \cdot \mathrm{kg}^{-1}\right) / \text { niższa wartość } \\
\text { opałowa }\end{array}$ & 42.7 & 39.0 \\
\hline Sulphur (mg·kg-1)/zawartość siarki & 46 & 5 \\
\hline $\begin{array}{l}\text { Total aromatics }(\% \text { wt.)/całkowita } \\
\text { zawartośc związów aromatycz- } \\
\text { nych }\end{array}$ & 24.1 & $<0.1$ \\
\hline $\begin{array}{l}\text { Molecular mass (eq.)/masa cza- } \\
\text { steczkowa (równoważnik) }\end{array}$ & 209 & 296 \\
\hline $\begin{array}{l}\text { Carbon (\% wt.)/węgiel } \\
\text { Hydrogen (\% wt.)/wodór }\end{array}$ & 86.5 & 77.2 \\
\hline Oxygen (\% wt.)/tlen & 0 & 12.0 \\
\hline
\end{tabular}

\subsection{Engine test condition and procedure}

Three different engine load and speed conditions shown in table 3 were selected for the test. These conditions are extracted from the New European Driving Cycle. The (cooled) EGR percentages were calculated and controlled by the EMS and are also shown in table 3. At this stage of study, no modification was made to the engine hardware or the EMS. In the test cell, the air temperature was controlled at $25 \pm 2^{\circ} \mathrm{C}$ while relative humidity was monitored. At the engine inlet, the temperature and the atmospheric pressure were measured and calculated to comply with the test validity, according to the Directive 1999/96/EC [11]. ultraniskosiarkowy (ULSD) oraz ester metylowy oleju rzepakowego (RME). Oba te paliwa dostarczane były przez Shell Global Solutions UK i odpowiadały normom europejskim EN 590 (w przypadku ULSD) oraz EN 14214 (w przypadku RME). Niektóre ich kluczowe właściwości podano w tabeli 2. We wszystkich warunkach pracy silnika przeprowadzano badania z użyciem dwóch składów paliwa: czysty ULSD oraz mieszanka 30\% (objętościowo) RME i 70\% ULSD (nazywana poniżej B30).

\subsection{Stany pracy silnika i procedury pomiarowe}

Do badań wybrano trzy zestawy warunków pracy silnika; prędkość i obciążenie podane są w tabeli 3. Warunki te wzięto z Nowego Europejskiego Cyklu NEDC. Udziały procentowe spalin recyrkulacyjnych (chłodzonych) były obliczane i kontrolowane przez system kontroli elektronicznej silnika EMS; są one także podane w tabeli 3. Na tym etapie badań nie wprowadzano żadnych modyfikacji do zespołów silnika ani też do systemu EMS. Temperatura powietrza $\mathrm{w}$ komorze hamowni była utrzymywana na poziomie $25 \pm 2^{\circ} \mathrm{C}$, a wilgotność względna była monitorowana. Temperatura $\mathrm{i}$ ciśnienie atmosferyczne na wlocie silnika były mierzone $\mathrm{i}$ przeliczane, tak aby spełniać warunki ważności pomiarów, zgodnie z dyrektywą 1999/96/EC [11].

Table 3. Engine test conditions

Tabela 3. Zestaw warunków pracy silnika

\begin{tabular}{|l|c|c|c|}
\hline $\begin{array}{l}\text { Engine con- } \\
\text { ditions/numer } \\
\text { zestawu }\end{array}$ & $\begin{array}{c}\text { Speed/prędkość } \\
\text { (rpm) }\end{array}$ & $\begin{array}{c}\text { Load/obciażenie } \\
\text { (bar BMEP) }\end{array}$ & EGR (\% vol.) \\
\hline C1 & 1550 & 3.1 & 0 \\
\hline C2 & 1550 & 3.1 & $48^{(\text {a) }}, 45^{(\mathrm{b})}$ \\
\hline C3 & 1550 & 4.7 & 0 \\
\hline C4 & 1550 & 4.7 & $34^{(\text {a) }}, 32^{\text {(b) }}$ \\
\hline C5 & 1850 & 4.4 & 0 \\
\hline C6 & 1850 & 4.4 & $37^{\text {(a) }}, 36^{(\text {b) }}$ \\
\hline
\end{tabular}

(a) for ULSD case/w przypadku ULSD

(b) for B30 case/w przypadku B30

\section{Wyniki i dyskusja}

\subsection{Rozkład ilościowy wielkości cząstek}

Wpływ obciążenia silnika i EGR na rozkłady ilościowe wielkości cząstek pokazany jest odpowiednio na rys. $2 \mathrm{a}$ i $2 \mathrm{~b}$. Ogólnie biorąc, przy pracy silnika bez EGR liczby cząstek o małych średnicach w aerozolu wydechowym są większe przy spalaniu B30 w porównaniu $\mathrm{z}$ aerozolem pochodzącym ze spalania ULSD.

Jedną z głównych przyczyn wzrostu liczby cząstek o małych rozmiarach może być wg Tsolakisa [8] przypisana wzrostowi ciśnienia wtrysku paliwa przy zasilaniu biodieslem, jak to pokazano na rys. 3. W badaniach z zastosowaniem układów wtryskowych paliwa typu pompa-przewód-wtryskiwacz często donoszono o wzroście ciśnienia wtrysku przy zastosowaniu biodiesla [12], a to ze względu na jego większą gęstość i lepkość [13] oraz objętościowy moduł ściśliwości [14]. W układach wtryskowych paliwa typu common rail zmiany właściwości fizycznych paliwa nie prowadzą automatycznie do przyspieszenia kąta wtry- 


\section{Results and discussion}

\subsection{Particle number size distribution}

The particle number size distributions are shown in Fig. $2 a$ and $2 b$ as affected by engine load and EGR respectively. Generally at the engine operation without EGR the particulate numbers of exhaust aerosol from B30 combustion are higher in smaller diameter compared with ULSD combustion aerosol.

One of the main reasons for the increase in the particulate number in small size according to Tsolakis [8] can

a)

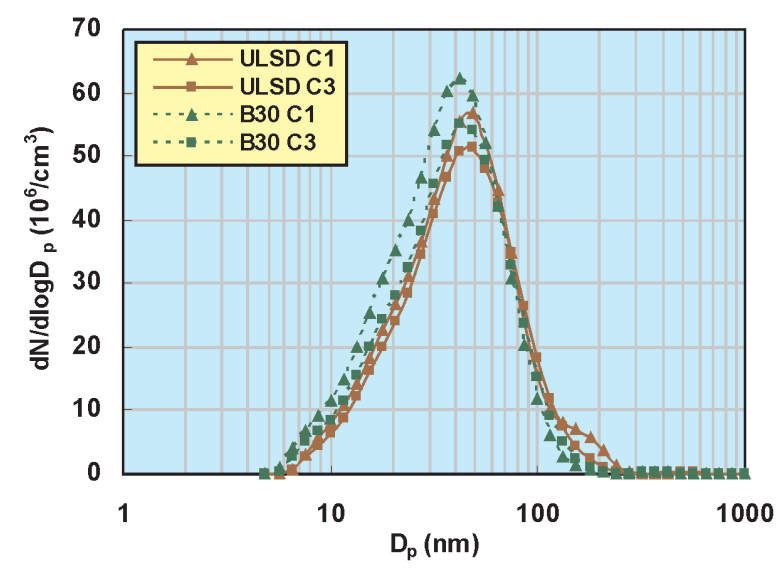

sku. Jednak w wyniku działania systemu kontroli silnika mimo wszystko następuje wzrost ciśnienia wtrysku paliwa. Prowadzi to do lepszej atomizacji paliwa przez wzrost liczby i przesunięcie rozkładu wielkości kropli paliwa do mniejszych rozmiarów. Oprócz tego, w przypadku spalania B30 w komorze spalania silnika, mieszanka paliwa zawierającego tlen obniża również liczbę cząstek zawierających węgiel przez zmniejszenie prędkości przemian gazu na cząstki stałe oraz zwiększa stopień utleniania paliwa w strefach bogatej mieszanki, gdzie tworzy się sadza [8].

b)

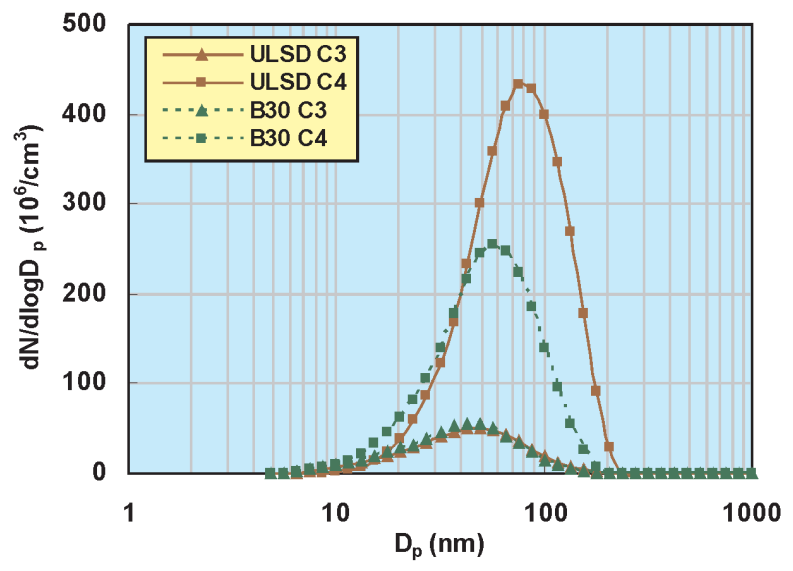

Fig. 2. Influence of (a) engine load and (b) exhaust gas recirculation on particle number size distribution Rys. 2. Wpływ (a) obciązenia silnika oraz (b) recyrkulacji spalin na rozkłady ilościowe wielkości czastek

be attributed to the increase in fuel injection pressure for biodiesel fuelling as shown in Fig. 3. In pump-line-injector fuel injection systems, the increased injection pressure have been reported frequently for the use of biodiesel [12], due to its higher density and viscosity [13] and bulk modulus of compressibility [14]. In common rail fuel injection systems, the physical properties of fuel do not lead to any injection advance. However the increase in fuel injection pressure still exists as a consequence of engine management system. This yields better fuel atomisation by increasing the number and shifting the fuel droplets to smaller sizes. In addition, for B30 combustion in the engine combustion chamber, the oxygen-contained fuel mixture also reduces carbon-contained PM by lowering the rate of gas-to-particulate conversion and enhances fuel oxidation in the fuel-rich zone where the soot is formed [8].

At constant engine speed without EGR in Fig. 2a, the engine load affects the characteristics of the exhaust gas aerosol as presented over the load range at $1550 \mathrm{rpm}$. It is seen for both ULSD and B30 that the particle number concentration reduced corresponding to the enlarged particle size as the engine load in-
Przy stałej prędkości silnika 1550 obr/min bez recyrkulacji spalin EGR, obciążenie silnika ma wpływ na charakterystykę aerozolu w gazie wydechowym, jak to przedstawiono na rys. 2 a dla dwóch wartości BMEP. Zarówno dla ULSD,

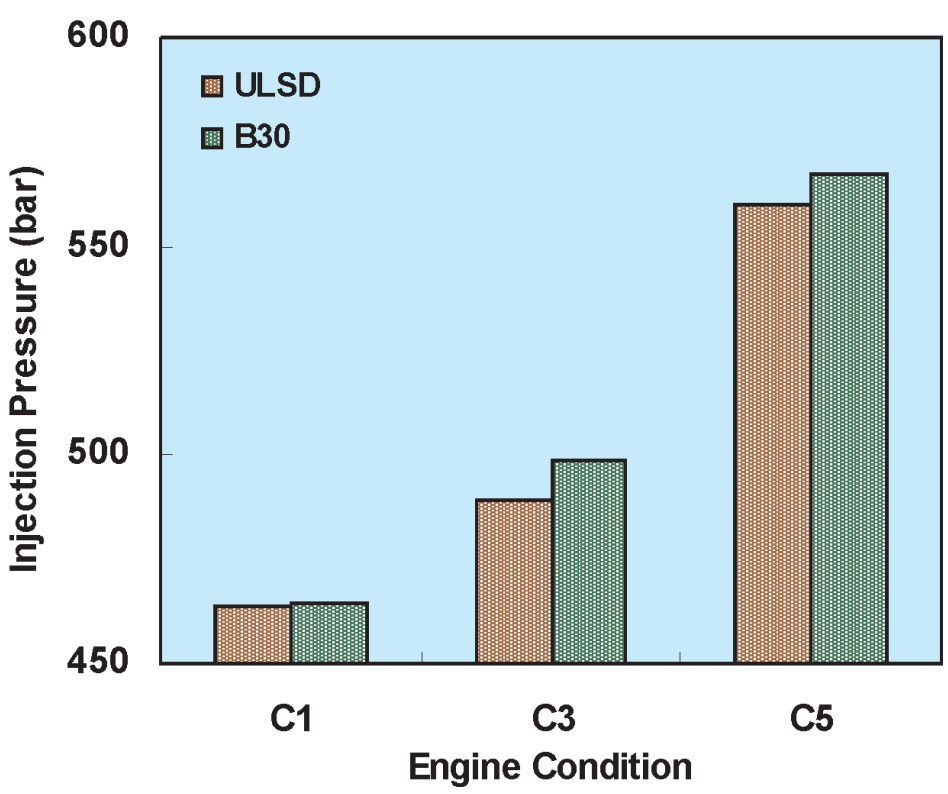

Fig. 3. Fuel injection pressure Rys. 3. Ciśnienie wtrysku paliwa 
creased. This suggests that higher degree of coagulation of nanoparticles occurred.

At constant engine load and speed, the EGR addition was also found to affect the particle number concentration as shown in Fig. 2b. The particle number in the diameter range of 40-200 $\mathrm{nm}$ has been increased noticeably by the EGR for both fuels but lesser extent for B30 case. The peaks of number concentrations are about 8 times for ULSD and 5 times for B30 higher than those without EGR. In this case, the greater amount of EGR rate applied for ULSD (34\%) may have been responsible for the higher number of ULSD aerosol in bigger diameter, compared with 32\% EGR for B30.

\subsection{Particles in nucleation and accumulation modes}

Figure 4 shows statistical analysis of total particle numbers and count mean diameter (CMD) in the nucleation and accumulation modes by the definition given in Section 2.2. For both modes, it is clear that both CMD and number concentration tend to increase with increased EGR rate. In the nucleation mode with and without EGR operation (Fig. $4 \mathrm{a}$ ), the total particle numbers have shown to be higher for B30 aerosol while the CMD were smaller for B30 for all conditions tested. At the engine operation without EGR, the averaged CMD and total particle number are $30.3 \mathrm{~nm}$ and $24.7 \times 10^{6} \mathrm{~cm}^{-3}$, respectively for ULSD exhaust gases while those are $28.9 \mathrm{~nm}$ and $28.1 \times 10^{6} \mathrm{~cm}^{-3}$, respectively for B30 exhaust gases. At the engine operation with EGR, the averaged CMD and total particle number are $39.5 \mathrm{~nm}$ and $73.5 \times 10^{6} \mathrm{~cm}^{-3}$, respectively for ULSD case while those are $34.8 \mathrm{~nm}$ and $79.1 \times 10^{6} \mathrm{~cm}^{-3}$ for B30 case. From the presented results, EGR seems to bring no significant changes in the primary particle size.

a)

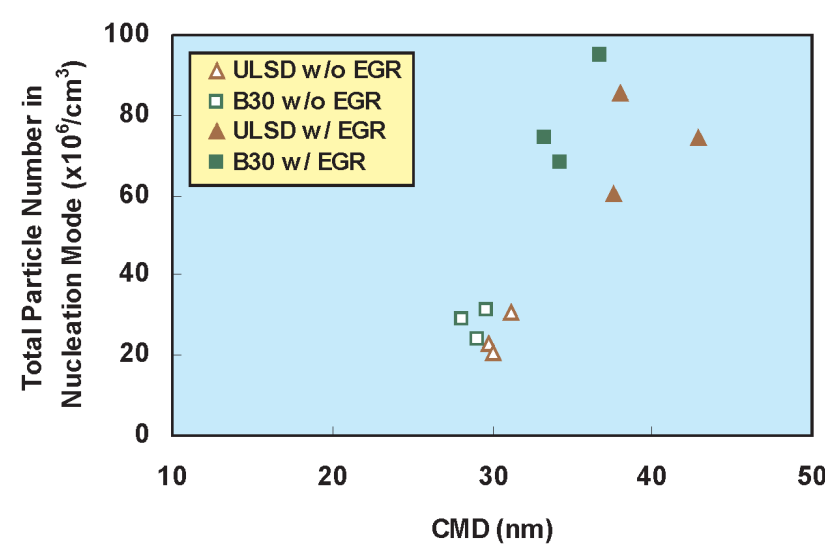

jak i dla B30 widać, że dla zwiększonego obciążenia silnika maleje koncentracja ilościowa cząstek odpowiadająca zwiększonym rozmiarom. Sugeruje to, że nastąpił zwiększony stopień koagulacji nanocząstek.

Przy stałej prędkości i obciążeniu silnika okazało się, że recyrkulacja spalin EGR również ma wpływ na koncentrację ilościową cząstek, jak to pokazano na rys. 2b. Liczba cząstek w zakresie średnic 40-200 nm wyraźnie wzrosła przy zastosowaniu recyrkulacji spalin EGR dla obu paliw, jednak w mniejszym stopniu w przypadku B30. Maksymalne wartości koncentracji ilościowej są w dla ULSD 8 razy wyższe, a dla B30 5 razy wyższe od wartości bez EGR. W tym przypadku większy procent EGR zastosowany dla paliwa ULSD (34\%) mógł być odpowiedzialny za wystąpienie większej liczby cząstek w aerozolu ULSD w porównaniu z 32\% EGR w przypadku paliwa B30.

\subsection{Czastki w zakresach zarodkowych i akumulacyjnych}

$\mathrm{Na}$ rysunku 4 przedstawiono analizę statystyczną całkowitej liczby cząstek i ich średniej średnicy zliczeniowej count mean diameter CMD) w zakresach zarodkowych i akumulacyjnych, zgodnie z definicją podaną w Sekcji 2.2. W obydwu zakresach jest oczywiste, że zarówno CMD, jak i koncentracja ilościowa wykazują tendencje wzrostowe dla większej proporcji EGR.

We wszystkich warunkach eksperymentalnych, zarówno przy użyciu EGR, jak bez recyrkulacji spalin (rys. 4a), całkowita liczba cząstek w zakresie nukleacyjnym okazała się większa w aerozolu pochodzącym ze spalania paliwa B30, natomiast średnia średnica zliczeniowa była mniejsza dla B30 niż dla ULSD. Przy pracy silnika bez EGR uśredniona wartość średniej średnicy zliczeniowej CMD i całkowita

b)

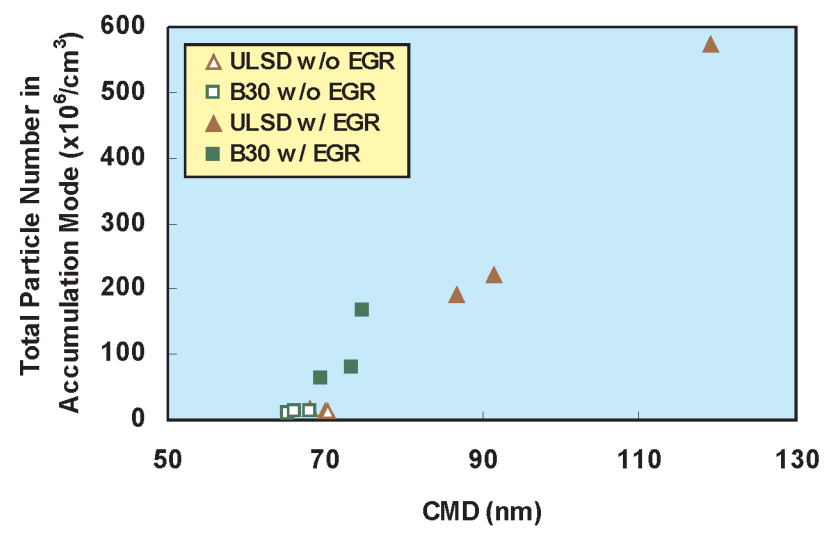

Fig. 4. Influence of exhaust gas recirculation on total particle number in (a) nucleation mode and (b) accumulation mode

Rys. 4. Wplyw recyrkulacji gazów wydechowych na całkowita liczbę cząstek w zakresie zarodkowym (nukleacyjnym) (a) $i$ akumulacyjnym (b)

In the accumulation mode with and without EGR operation (Fig. 4b), compared to ULSD case, the smaller CMDs and the lower total numbers from B30 combustion have been observed for all conditions tested. At the engine operation without EGR, the averaged CMD and total particle number are $69.5 \mathrm{~nm}$ and $15.2 \times 10^{6} \mathrm{~cm}^{-3}$, respectively for liczba cząstek wynoszą dla gazów wydechowych ze spalania paliwa ULSD odpowiednio $30,3 \mathrm{~nm}$ oraz $24,7 \times 10^{6} \mathrm{~cm}^{-3}$, natomiast w przypadku gazów wydechowych z B30 wynoszą one odpowiednio 28,9 $\mathrm{nm}$ i $28,1 \times 10^{6} \mathrm{~cm}^{-3}$. Przy pracy silnika z EGR uśredniona średnica zliczeniowa CMD i całkowita liczba cząstek wynoszą dla paliwa ULSD odpowiednio 39,5 
ULSD exhaust gases while those are $66.3 \mathrm{~nm}$ and $13.0 \times 10^{6}$ $\mathrm{cm}^{-3}$, respectively for B30 exhaust gases. At the engine operation with EGR, the averaged CMD and total particle number are $99.1 \mathrm{~nm}$ and $327.9 \times 10^{6} \mathrm{~cm}^{-3}$, respectively for ULSD case while those are $72.6 \mathrm{~nm}$ and $104.1 \times 10^{6} \mathrm{~cm}^{-3}$ for $\mathrm{B} 30$ case. It is apparently that EGR results in noticeable changes in particle size and number in accumulation mode.

\subsection{Total particle number}

Figure 5 shows the total particle number for all test conditions versus the corresponding count mean diameter (CMD) of the distributions. For the calculation of the CMD, the whole particle size range $(5 \mathrm{~nm}$ to $1,000 \mathrm{~nm}$ ) was considered. The B30 combustion reduced particle size and lowered total particle number in exhaust gas emitted from the engine with EGR but the number was higher as the engine operated without EGR, compared to the ULSD case. For both fuels, the correlation shows obviously that the higher the number of particles, the higher the CMD. This is due to the fact that larger aggregates are formed when the particle number increases [15].

The effect of EGR on particles as indicated in Fig. 5 has revealed that - for ULSD, it makes noticeable difference to the particle number at mobility diameter larger

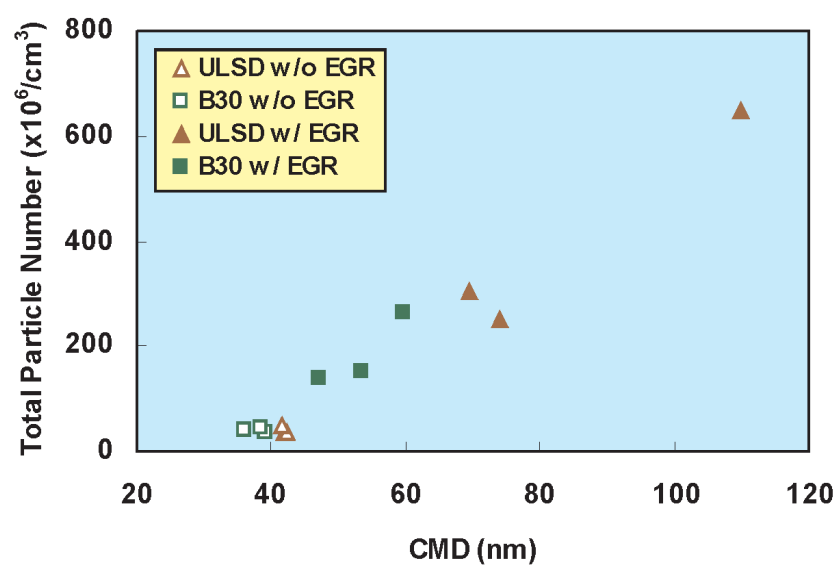

Fig. 5. Total particle number (comprising nucleation mode and accumulation mode)

Rys. 5. Catkowita liczba cząstek (biorąc pod uwagę cząstki w zakresach zarodkowym - nukleacyjnym i akumulacyjnym)

than $50 \mathrm{~nm}$, but for $\mathrm{B} 30$, it reduces considerably the number of particles. Potentially, reducing or maintaining the particle number at low mobility diameters can be proficiently carried out by optimising EGR addition. However care has to be taken since this process may increase the total PM number in larger sizes. In contrast, with biodiesel, this can bring benefits to the reduction of total particle number at high mobility diameters for modern electronic-controlled diesel engines with common rail fuel injection system such as the engine used in the present study. nm i $73,5 \times 10^{6} \mathrm{~cm}^{-3}$, natomiast dla B3 - odpowiednio 34,8 $\mathrm{nm}$ i $79,1 \times 10^{6} \mathrm{~cm}^{-3}$. Z przedstawionych rezultatów wynika, że zastosowanie EGR nie powoduje znaczących zmian w rozmiarach cząstek pierwotnych (nukleacyjnych).

W zakresie akumulacyjnym wielkości cząstek (rys. 4b), we wszystkich warunkach pracy silnika: z EGR i bez recyrkulacji, dla zasilania paliwem B30 zaobserwowano mniejsze średnie średnice zliczeniowe CMD i mniejsze całkowite liczby cząstek w porównaniu z zasilaniem paliwem ULSD. Przy pracy bez recyrkulacji spalin EGR uśredniona średnica zliczeniowa CMD i całkowita liczba cząstek to dla paliwa ULSD odpowiednio $69,5 \mathrm{~nm}$ i $15,2 \times 10^{6} \mathrm{~cm}^{-3}$, natomiast dla gazów spalinowych z zasilania paliwem B30 - odpowiednio $66,3 \mathrm{~nm}$ i $13,0 \times 10^{6} \mathrm{~cm}^{-3}$.

Wskazuje to, że zastosowanie recyrkulacji spalin EGR powoduje zauważalne zmiany w rozmiarach i liczbie cząstek w zakresie akumulacyjnym.

\subsection{Całkowita liczba cząstek}

$\mathrm{Na}$ rysunku 5 przedstawiono całkowitą liczbę cząstek w funkcji odpowiadających im średnich wielkości zliczeniowych (CMD) w rozkładach uzyskanych dla wszystkich warunków eksperymentalnych. Średnie wielkości zliczeniowe były obliczane dla całego zakresu wielkości cząstek (od $5 \mathrm{~nm}$ do $1000 \mathrm{~nm}$ ). Spalanie paliwa B30 w porównaniu z paliwem ULSD daje mniejsze rozmiary i mniejszą całkowitą liczbę cząstek w gazach spalinowych w przypadku zastosowania recyrkulacji spalin EGR, lecz bez EGR liczba cząstek była większa dla B30. Korelacje dla obydwu paliw wskazują, że im większa jest liczba cząstek, tym większa jest ich średnia średnica zliczeniowa CDM. Wynika to z faktu, że wzrost liczby cząstek prowadzi do tworzenia się większych ich agregatów [15].

Wpływ recyrkulacji spalin EGR na cząstki stałe w spalinach przedstawiony na rys. 5 ukazuje, że w przypadku paliwa ULSD zastosowanie EGR prowadzi do zauważalnych zmian liczby cząstek o średnicach mobilności większych od $50 \mathrm{~nm}$, natomiast w przypadku paliwa B30 prowadzi ono do znaczącego zmniejszenia liczby cząstek. Kompetentna optymalizacja zastosowania recyrkulacji spalin może potencjalnie prowadzić do zmniejszenia lub przynajmniej utrzymania liczby cząstek o małych średnicach mobilności. Należy jednak zachować ostrożność, ponieważ proces ten może prowadzić do zwiększenia całkowitej liczby cząstek o większych rozmiarach. Tym niemniej, w przypadku paliwa typu biodiesel spalanego w sterowanych elektronicznie nowoczesnych silnikach o zapłonie samoczynnym z układem wtryskowym common rail, takich jak silnik użyty w przedstawionych tu badaniach, może to przynieść korzyści przez obniżenie całkowitej liczby cząstek o dużych średnicach mobilności.

\section{Wnioski}

Badania eksperymentalne rozkładów wielkości cząstek stałych i całkowitej liczby cząstek w aerozolu gazu wydechowego ze spalania paliwa niskosiarkowego ULSD i jego mieszanki z 30. procentami estru oleju rzepakowego B30 w 


\section{Conclusions}

An experimental study on the particle size distribution and total particle number in distinct mode of exhaust gas aerosol from ULSD and B30 combustion in a common rail fuel injection diesel engine has revealed the conclusions as follows:

1. The particle number size concentrations are dependent of engine operating condition and also varied with the differences in EGR rate applied to the engine when the different fuels were used.

2. At constant engine speed without EGR, the particle number concentration reduced corresponding to the enlarged particle size as the engine load increased, due to coagulation of particles for both fuels.

3. When the engine load and speed were fixed, the particle number concentration increased noticeably by the EGR mainly in the diameter range of 40-200 $\mathrm{nm}$ for both fuels but lesser extent for B30 case.

4. In the nucleation mode regardless of EGR, the total particle numbers were higher while the sizes were smaller for $\mathrm{B} 30$ for all conditions tested. From the presented results, EGR shows to bring insignificant changes to the primary particle size.

5. In the accumulation mode regardless of EGR, compared to ULSD case, the smaller sizes and the lower total numbers from B30 combustion were observed for all conditions tested. EGR results in noticeable changes in particle size and number in accumulation mode.

6. For both modes and both fuels, particle number concentration and size tend to increase with EGR, due to the larger aggregates formed when the particle number enlarges.

7. Compared to the ULSD case, the B30 combustion reduced particle size and lowered total particle number in exhaust gas emitted from the engine with EGR but the number was higher as the engine operated without EGR.

\section{Acknowledgement}

This work was conducted at the University of Birmingham; cooperation of the members in the Future Engines and Fuels Lab is gratefully appreciated. The authors wish to acknowledge Jaguar Cars Ltd for the financial and technical support and Shell Global Solutions UK for the provision of the test fuels. Dr S. Chuepeng would like to thank the Royal Thai Government for his Ph.D. scholarship and maintenance grant.

\section{Nomenclature/Skróty i oznaczenia}

BMEP Brake Mean Effective Pressure/średnie efektywne ciśnienie obciążenia

BOC British Oxygen Company

CMD Count Mean Diameter/średnica średnia zliczeniowa

rpm Revolution per Minute/obroty na minute silniku ZS z wtryskiem paliwa typu common rail pozwalają na wyciągniecie następujących wniosków:

1. Rozkłady liczby cząstek $w$ funkcji ich wielkości są zależne od warunków pracy silnika i zmieniają się również ze zmianami proporcji strumienia recyrkulacji spalin EGR stosowanymi w silniku w przypadkach używania różnych paliw.

2.Przy pracy silnika ze stałą prędkością bez recyrkulacji spalin, w miarę wzrostu obciążenia silnika następowało dla obydwu paliw zmniejszenie koncentracji ilościowej cząstek połączone ze wzrostem ich rozmiaru, spowodowane koagulacją cząstek.

3.Przy stałym obciążeniu i prędkości silnika koncentracja ilościowa cząstek znacznie wzrasta, gdy zastosowana jest recyrkulacja spalin EGR; wzrost ten występuje głównie w zakresie średnic 40-200 nm dla obydwu paliw, przy czym jest on mniejszy dla paliwa B30.

4. W zakresie wielkości cząstek pierwotnych (zwanych też zarodkowymi lub nukleacyjnymi) całkowita liczba cząstek była większa, a rozmiary cząstek mniejsze w przypadku paliwa B30 dla wszystkich warunków eksperymentalnych. $\mathrm{Z}$ przedstawionych rezultatów wynika, że zastosowanie recyrkulacji spalin powoduje jedynie nieznaczne zmiany w rozmiarach cząstek pierwotnych.

5. W zakresie wielkości cząstek akumulacyjnych, niezależnie od zastosowania recyrkulacji spalin i dla wszystkich warunków eksperymentalnych, dla paliwa B30 uzyskano mniejsze wielkości i mniejszą liczbę cząstek w spalinach w porównaniu z paliwem ULSD.

6. W obydwu zakresach wielkości cząstek i dla obydwu zastosowanych paliw zarówno koncentracja ilościowa (liczbowa), jak i wielkość cząstek wzrastają przy zastosowaniu recyrkulacji spalin EGR, z powodu tworzenia się większych aglomeratów cząstek przy wzroście ich liczby.

7. Spalanie paliwa B30 z zastosowaniem recyrkulacji spalin EGR powoduje, w porównaniu ze stosowaniem paliwa ULSD, zmniejszenie rozmiarów cząstek oraz całkowitej ich liczby w gazie wydechowym, natomiast w przypadku pracy silnika bez recyrkulacji spalin liczba cząstek była dla B30 większa.

\section{Podziękowania}

Badania zostały przeprowadzone w Uniwersytecie Birmingham; z wdzięcznością zaznaczamy współpracę członków Laboratorium Silników i Paliw Przyszłości. Autorzy pragną także podziękować firmie Jaguar Cars Ltd za pomoc finansową i techniczną oraz firmie Shell Global Solutions UK za dostarczenie paliw. Doktor S. Chuepeng pragnie wyrazić wdzięczność Królewskiemu Rządowi Tajlandii za przyznane mu stypendium doktoranckie.

Paper reviewed 


\section{Bibliography/Literatura}

[1] Graboski M.S., McCormick R.L.: Combustion of fat and vegetable oil derived fuels in diesel engines. Progress in Energy and Combustion Science vol. 24, pp. 125-164, 1998.

[2] Directive 2003/30/EC: The promotion of the use of biofuels or other renewable fuels for transport. Official Journal of the European Union L123, pp. 42-46, 2003.

[3] Lapuerta M., Armas O., Rodíguez-Fernández J.: Effect of biodiesel fuels on diesel engine emissions. Progress in Energy and Combustion Science vol. 34, pp. 198-223, 2008.

[4] Sharp C.A., Howell S.A., Jobe J.: The effect of biodiesel fuels on transient emissions from modern diesel engines, part II unregulated emissions and chemical characterization. SAE Transaction vol. 109, pp. 1784-1807, 2000.

[5] Kittelson D.B.: Engines and nanoparticles: a review. Journal of Aerosol Science vol. 29, pp. 575-588, 1998.

[6] Van Gulijk C., Marijnissen J.C.M., Mekkee M., Moulijn J.A., Schmidt-Ott A.: Measuring diesel soot with a scanning particulate sizer and an electrical low-pressure impactor: performance assessment with a model for fractallike agglomerates. Aerosol Science, vol. 35, pp. 633-655, 2004.

[7] Tsolakis A., Hernandez J.J., Megaritis A., Crampton M.: Dual fuel diesel engine operation using $\mathrm{H}_{2}$. Effect on particulate emissions. Energy \& Fuels vol. 19, pp. 418-425, 2005.

[8] Tsolakis A.: Effects on particulate size distribution from the diesel engine operating in RME-biodiesel with EGR. Energy \& Fuels vol. 20, pp. 1418-1424, 2006.

[9] Chuepeng S., Theinnoi K., Tsolakis A., Xu H.M., Wyszynski M.L., Yor A.P.E., Hartland, J.C., Qiao J.: Investigation into particulate size distributions in the exhaust gas of diesel engines fuelled with biodiesel blends. Journal of KONES Powertrain and Transport vol. 15. ISSN 12341-4005, 2008.

[10] European Commission: Biofuels in the European Union a vision for 2030 and beyond [online]. http://ec.europa.eu/ research/energy/pdf/biofuels_vision_2030_en.pdf, 2006.

[11] Directive 1999/96/EC: The approximation of the laws of the Member States relating to measures to be taken against the emission of gaseous and particulate pollutants from compression ignition engines for use in vehicles, and the emission of gaseous pollutants from positive ignition engines fuelled with natural gas or liquefied petroleum gas for use in vehicles and amending Council Directive 88/77/ EEC. Official Journal of the European Union L44, pp. 1-155, 2000.

[12] Szybist J.P., Boehman A.L.: Behavior of a diesel injection system with biodiesel fuel. SAE Paper No. 2003-01-1039, 2003.

[13] Rakopoulos C.D., Hountalas D.T.: A simulation analysis of a DI diesel engine fuel injection system fitted with a constant pressure valve. Energy Conversion and Management vol. 37, No. 2, pp. 135-150, 1996.

[14] Tat M.E., Van Gerpen J.H.: Physical properties and composition detection of biodiesel - diesel fuel blends. ASABE Paper No. 026084, 2002.

[15] Desantes J.M., Bermúdez V., García J.M., Fuentes E.: Effects of current engine strategies on the exhaust aerosol particle size distribution from a heavy-duty diesel engine. Aerosol Science vol. 36, pp. 1251-1276, 2005.
Mr. Sathaporn Chuepeng, BEng, MEng, PhD - Lecturer in Mechanical Engineering, Faculty of Engineering at Si Racha, Kasetsart University, Thailand.

Dr inż. Sathaporn Chuepeng - adiunkt, Wydziat Inżynierski w Si Racha, Uniwesytet Kasetsart, Tajlandia.

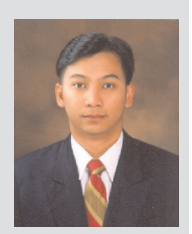

Mr. Hongming Xu, BEng, MEng, PhD, DIC, MSAE, CEng, FIMechE - Reader in Automotive Engineering, School of Mechanical Engineering, the University of Birmingham, UK.

Dr inż. Hongming $X u-$ docent inżynierii samochodowej, Wydzial Mechaniczny, Uniwersytet Birmingham, Wielka Brytania.

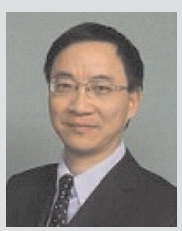

Mr. Athanasios Tsolakis, BEng, PhD, MIMechE - Lecturer in Automotive Engineering, School of Mechanical Engineering, the University of Birmingham, UK.

Dr inż. Athanasios Tsolakis, MIMechE - adiunkt inżynierii samochodowej, Wydział Mechaniczny, Uniwersytet Birmingham, Wielka Brytania.
Mr. Miroslaw L. Wyszynski, MEng PhD, MSAE, MSIMP, PTNSS - Professor of Novel Vehicle Technology and Applied Thermodynamics, Mechanical Engineering, the University of Birmingham, UK.

Prof. dr inż. Mirosław L. Wyszyński,-Profesor Nowych Technik Samochodowych i Termodynamiki Stosowanej, Wydziat Mechaniczny, Uniwersytet Birmingham, Wielka Brytania.

Mr. Jonathan Hartland, PhD - Senior Engineer, Jaguar Cars Ltd, UK.

Dr inż. Jonathan Cartland - starszy inżynier, Jaguar Cars Ltd, Coventry, Wielka Brytania.
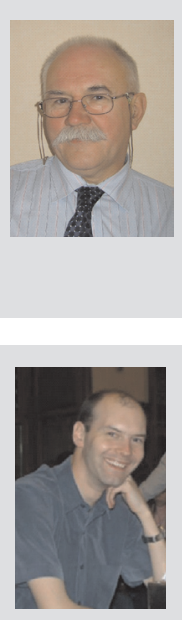